Bryn Mawr College

Scholarship, Research, and Creative Work at Bryn Mawr

College

Political Science Faculty Research and Scholarship

Political Science

1999

\title{
Women, Bargaining and Change in Seven Structures of World Political Economy
}

Michael H. Allen

Bryn Mawr College, mhallen@brynmawr.edu

Let us know how access to this document benefits you.

Follow this and additional works at: http://repository.brynmawr.edu/polisci_pubs

Part of the Political Science Commons

\section{Custom Citation}

Allen, Michael H. "Women, Bargaining and Change in Seven Structures of World Political Economy." Review of International Studies 25 (1999): 453-474.

This paper is posted at Scholarship, Research, and Creative Work at Bryn Mawr College. http://repository.brynmawr.edu/polisci_pubs/14

For more information, please contact repository@brynmawr.edu. 


\title{
Women, bargaining and change in seven structures of world political economy
}

\author{
MICHAEL ALLEN*
}

\begin{abstract}
Feminist discourses have changed the vision of the issues and sites of political encounter that are important for study in IR. IPE scholars have also been reframing the discipline by their focus upon other agents besides states, and other structures of power and change, besides those of security and production. But these discourses could also complement each other to mutual benefit. This article suggests ways to do that, by positing a framework of analysis through which IPE, Feminist, International-Legal/Institutional, Peace and other critical discourses could intersect. It suggests that world political economy be conceived of in terms of seven intersecting, dynamic structures, in which some common historical processes unfold. These include bargaining and rivalry, realist self-interest and morally enlightened action. This goes beyond the four structures already recognised in critical IPE discourse, and the dichotomous materialist or idealist assumptions about agent motivations, in mainstream IR. By including Nurture/Reproduction as one of the seven structures, women's agency, with its possibilities and limits, cannot be missed in the normal business of the discipline.
\end{abstract}

It has been asserted that women have been marginal in world political economy and virtually invisible in theories of International Political Economy (IPE) ${ }^{1}$ It is suggested below that while women have indeed been marginalised from powerful roles in formal production for the market, finance, security, law and diplomacy, they have been centrally involved in other vital activities in the world economy that directly affect these systems.

IPE scholars have expanded the range of analysis that can be considered mainstream IR, or have challenged the projects of that mainstream itself. This largely reflects the reality that economic, technological and ecological factors have become at least as important as arms and territory used to be, in determining who has power in the world, and how it is used. ${ }^{2}$ An immediate concern here is to show that the conceptualisation of women's roles and power in the world economy is also necessary even in the newer analysis that IPE scholars have brought to the field of IR.

\footnotetext{
* My thanks to Dr. Barry Gills and Professor Susan Strange for helpful comments on this article, a version of which was first presented at the British International Studies Association (BISA) Annual Conference in 1996. Special thanks to two anonymous reviewers at Review of International Studies and especially Professor Mary Osirim of the Department of Sociology at Bryn Mawr College.

${ }^{1}$ See Sandra Whitworth, 'Theory as Exclusion: Gender and International Political Economy', in Richard Stubbs and Geoffrey Underhill (eds.) Political Economy and the Changing Global Order (New York: St. Martin's Press, 1994). Other feminist critics of International Studies reinforce this point, such as Jill Steans Gender and International Relations: An Introduction (New Brunswick, NJ: Rutgers University Press, 1998), particularly ch. 7.

2 The essays in Nicolas I. Rizopaulos (ed.) Sea Change (New York: Council on Foreign Relations Press, 1991), speak on this point. In particular, see Susan Strange's 'The Name of the Game'.
} 
The realities they address are interconnected and are all, at some level, also gendered issues. ${ }^{3}$ An immediate particular discourse that is typified in the work of Susan Strange is suggested. It gives a basis for integrating the treatment of apparently distinct IR questions within an IPE approach. Some ways of organising a more inclusive vision of IPE are suggested, that build upon conceptualisations of bargaining as a paradigm of change in political-economy. ${ }^{4}$

Questions of gender have been important in the latest round of paradigmatic challenges and debates in IR. ${ }^{5}$ Feminists, like IPE scholars, are changing the field. ${ }^{6}$ Both suggest a redrawing of the boundaries of the field of IR. ${ }^{7}$ Neither the gender nor the IPE critique of IR orthodoxy are monolithic, each subsuming its own active debates. $^{8}$ Yet both have sought ways to theorise the presence, power, ideologies and impacts of agencies in world society beyond the usual states, firms, intergovernmental organisations and guerrilla armies. Both have begun to rework the core of the field of IR to reflect the newly-included elements.

In the process, some basic theoretical issues have been revisited. These have included the nature and origins of political awareness, the sources of social change, and the possibilities for knowing and communicating valid abstractions about social

${ }^{3}$ An important contribution to the integrated analysis of peace, development and ecology in gendered terms is Jennifer Turpin and Ann Lovrentzen (eds.), The Gendered New World Order: Militarism Development and the Environment (New York and London: Routledge, 1996). See their 'Introduction'.

${ }^{4}$ Essentially, bargaining is one technique of political encounter among others that include coercion, willing submission, incoherent conflict, and altruistic co-operation. Bargaining is an exacting exchange between agencies that are connected to the same problems, and is touched-off by changes in power or awareness. It is needed in political economy to construct and rearrange social networks. It is the archetype at work in coherent argumentation. I have used bargaining as an organising concept in IPE in previous work. See Michael H. Allen 'Rival Workers: Bargaining Power and Justice in Global Systems', in Roger Morgan et al. (eds.) New Diplomacy in the Post-Cold War World: Essays for Susan Strange (London: Macmillan, 1993).

5 It has been suggested that previous rounds of debate in IR since that between Liberal Internationalism (Idealism) and Realism had been permutations of the latter, until critical questions about agencies other than states were raised. See Michael Banks 'The Evolution of International Relations Theory', in Michael Banks (ed.) Conflict in World Society: A New Perspective on International Relations (Sussex, UK: Wheatsheaf, 1984). Even then, gender was left out as Marilyn Myerson and Susan Stoudinger Northcutt show in 'The Question of Gender: An Examination of Selected Textbooks in International Relations' International Studies Notes, 19:1 (1994), pp. 19-25.

6 An example of the initial stance of IPE scholars is found in Craig Murphy and Roger Tooze (eds.) The New International Political Economy (Boulder, CO: Lynne Rienner, 1991). The femininst impact is surveyed in Adam Jones 'Does "Gender" Make the World Go Round? Feminist Critiques of International Relations', Review of International Studies, 22:4 (1996). See also Jill Steans Gender and International Relations, 1998 (cited in fn. 1).

7 The traditional concerns of IR have been primarily war and peace issues and secondarily wealth and poverty, and how these two axes intersect from the perspectives of states. IPE scholars like Susan Strange have redrawn IR boundaries to include the agencies that create intersecting dynamics of security, production, finance and knowledge. See Strange States and Markets: An Introduction to International Political Economy (New York: Blackwell, 1988). Feminist scholars like Turpin and Lorentzen include ecological issues with military and developmental issues within their purview. See Turpin and Lorentzen (eds.) The Gendered New World Order, 1996.

8 Surveys of debates in IPE speak of a Realist/ Mercantilist, Liberal and Radical spectrum. See Roger Tooze 'Perspectives and Theory: A Consumer's Guide', in Susan Strange (ed.), Paths to International Political Economy (London: Allen and Unwin, 1984); or Geoffrey Underhill 'Introduction; Conceptualizing the Unchanging Global Order', in R. Stubbs and G. Underhill (eds.), Political Economy and the Changing Global Order (New York: St. Martin's Press, 1994). The spectrum of perspectives among feminists includes Liberals, Radicals, Essentialists and Standpoint theorists and feminist critical theorists. See ch. 7 of Steans Gender and International Relations (cited in fn. 1). 
and political reality despite the editorial effects of standpoint bias. ${ }^{9}$ The prominence of such basic theoretical issues in the current wave of critical debate in IR is reminiscent of an earlier one between the 'Wisdom' and 'Scientific' schools of Realism. ${ }^{10}$ Now, as then, there is a risk of losing sight of the concrete concerns for which critical theory should ultimately be relevant. Hence, one goal of this contribution is to connect practical and critical questions within a serviceable analytical framework.

This is not a gendered analysis in the sense that Gilligan or Sapiro would recognise. ${ }^{11}$ It speaks of women and men without presuming that any psychological differences between them as genders always translate into distinctly different patterns of change and justice for specific institutions or social contexts. It does accept with Bretherton that gender is socially constructed in given contexts. ${ }^{12}$ Gendered roles, for the most part, mean empowerment of some men and marginalization of others, and of most women. Hence political and economic projects that are conceived and executed in gender-neutral terms frequently do additional harm, especially to women, even if they also otherwise do some good. ${ }^{13}$ But such outcomes seem to be functions of differences in social and economic roles, reinforced by ideology, rather than of an essentially male or female way of thinking. Perspectives do matter but they vary not only by gender, but also by socialisation, ethnicity and class. ${ }^{14}$ The approach taken here is sceptical of essentialised standpoint epistemologies. It attempts to engage in coherent bargaining between the critical insights of IPE scholars about core issues in the world economy and the inescapable questions of justice from varied gendered perspectives.

\section{Radical critiques of orthodoxy and feminist responses}

The old questions at the core of international studies were: how is security to be established and maintained, and, how is national wealth to be protected or

9 This critical conversation is pursued in articles such as Randall Germain and Michael Kenny 'International Relations and the New Gramscians', Review of International Studies, 24:1 (1998), and Wade L. Huntley 'An Unlikely Match? Kant and Feminism in IR Theory', Millennium Journal of International Studies, 26:2 (1997). Basic questions of IR epistemology are also raised in the Introduction and essays edited by V. Spike Peterson, Gendered States: Feminist (Re)visions of International Relations Theory (Boulder, CO: Lynne Rienner, 1992).

${ }^{10}$ See again, Michael Banks 'The Evolution of International Relations Theory' in Conflict in World Society (Sussex, UK: Wheatsheaf, 1984).

11 This refers to the essentialist stance in feminism as advanced in the work of Carol Gilligan such as 'Visions of Maturity', in In a Different Voice: Psychological Theory and Women's Development (Cambridge, MA: Harvard University Press, 1982). See also Virginia Sapiro 'Gender Politics, Gendered Politics: The State of the Field' quoted in Jones, Review of International Studies (October 1996), p. 407.

12 See Charlotte Bretherton, 'Global Environmental Politics' in Review of International Studies, 24:1 (1998), p. 85.

13 Steans, Gender and International Relations, ch. 6. See also Bina Agarwal A Field of One's Own: Gender and Land Rights in South Asia (Cambridge: Cambridge University Press, 1994).

14 I am sceptical of standpoint epistemologies. Not all women or men in a given social context think alike and it is difficult to distill several lived experiences to authenticate a single epistemology. I prefer Henrietta Moore's suggestion that different cultures negotiate different arrangements of men's and women's gender roles. See her 'Balancing Acts: Gender at the Turn of the Century', LSE Magazine, 8:1 (1996), pp. 10, 11. 
increased? 'Security' in the first question meant, the independence and territorial integrity of the state (government and land). 'National' in the second question used to mean landowners mainly, then later also included merchants, bankers and industrialists. The old answer to the first question was: deter aggression by military preparedness or by alliances with other states who feared the same states more then they feared yours. In other terms, be a Realist. The old answer to the second question was: protect your territory and your ships, penetrate foreign markets and restrict access to your own, unless you are quite sure that, in a free trade environment, your nationals will export more than they import. In other terms, in addition to being a Realist, be Mercantilist unless you are sufficiently advanced in your productive and financing capability to be a Liberal. Make sure you can defend what you earn and your right to earn it, first with ideas and rules, then with bargaining power in markets, but also with force, if necessary. ${ }^{15}$

Contemporary questions in international relations derive from a greater appreciation of the inseparable realities of ecology, technology, ethnicity, class and gender. ${ }^{16}$ The agents whose attitudes, actions and power must be considered, include not only states, firms and banks, but also male and female workers, householders, parents and other socializers and teachers of the young, legal and illegal informal traders, and non-state users of force in guerrilla armies, and criminal syndicates.

Both the Realist and Liberal perspectives focus on too narrow a band of agentsstates and firms - and universalises the analysis of their motivations and actions. Even among states, outlooks, motivations and practices vary. ${ }^{17}$ Non-state and nonfirm agents are examined in the established tradition, only to the extent that they are deemed to affect security and accumulation strategies. Yet these are offered as the paradigms of approach to the concerns of the other agents in world society. What began before the industrial age as the openly ideological project of aristocratic states and, later, of emergent industrialists and financiers has, over a century or so, been elevated to the realm of positive universal theory. Despite the scientific dress, the paradigms retain their ideological character. When seen in this way, it becomes easier to juxtapose approaches that address questions of concern to other agents in world society, including women.

This leads to the question: what changes in analytical approach in IPE might make women's agency in world political-economy visible and normal without, in turn, obscuring other unrecognised agents or the traditionally recognised ones, such as states and firms?

15 A useful distinction can be made between 'Realism' and 'realism'. The first, Realism, is a recognized tradition in IR concerned with the problem of order among states. The second, realism, is an outlook on social change that sees politics in terms of competition or conflict among self-interested agents. Hence Realism is the realism of states and Liberalism is the realism of markets, Marxism the realism of classes and so on.

${ }^{16}$ See Turpin and Lorentzen (eds.) The Gendered New World Order, 'Introduction' and ch. 1 'Women, Gender, Feminism and the Environment', by Lorraine Elliot, pp. 13-34.

17 Petras, for example demonstrates that given states change in outlook and motivation, depending on the configuration of social forces that support their incumbency. See James Petras, Critical Perspectives on Imperialism and Social Class in the Third World, Monthly Review, NY (1978), ch. 1. See also Robert Cox 'Social Forces, States and World Orders: Beyond International Relations Theory', in Robert O. Keohane (ed.), Neorealism and its Critics (New York: Columbia University Press, 1986). 
Feminist scholars like Steans, Whitworth and Tickner have joined the critique of Realism/Mercantilism and Liberalism. ${ }^{18}$ The main critical points are endorsed. But they also criticise Marxism and Dependency/World Systems Theory for some of the same failings, namely positive universalism in assumptions about agent motivations - classes in this case - and subsuming gender dialectics in analyses of class conflict (Marxists) and structural constraints (Dependencia). Despite being openly ideological theories with a preference for justice in political-economy, Marxism and Dependencia paradigms are regarded as almost equally guilty with Realism and Liberalism in making women's agency invisible in IPE. Feminists question the assumption that men and women bring undifferentiated motivations to economic activity at any level. From the perspective of black and brown women in the South, Reddock adds the criticism that questions of race and ethnicity, besides gender, are subsumed to class in the Marxian and Dependency traditions, and of course, largely ignored in the Realist and Liberal ones. ${ }^{19}$ She argues for an analysis that recognises the mutually reinforcing dynamics of all forms of oppression.

\section{Feminist contributions to IPE}

Feminist scholars have done research upon the following features of the world economy that are ignored in established approaches:

- Women are under-represented in the most powerful levels of institutions and roles in the world economy such as industry, the creation and distribution of credit, making and adjudicating laws, and the control of force. ${ }^{20}$

- Women produce most of the child and elder care in all countries, and for the most part do so as unpaid labour. ${ }^{21}$

- More women than men produce the world's food.2

- Women are the first socializers of oncoming generations of male and female workers, consumers, voters and parents, that is, are powerful transmitters of the values that shape both the quality of human resources and the disposition of consumer demand. The quality of nurture (emotional, physical and intellectual)

18 Steans, Gender and International Relations; Whitworth 'Theory as Exclusion'; J. Ann Tickner 'On the Fringes of the World Economy: A Feminist Perspective', in Murphy and Tooze (eds.), The New International_Political Economy, 1991.

19 Rhoda Reddock, 'Primacy of Gender in Race and Class', in J. Edward Greene (ed.), Race, Class and Gender in the Future of the Caribbean (Mona, Jamaica: Institute of Social and Economic Research, 1993).

20 Ann Tickner, 'Hans Morganthau's Principles of Political Realism: A Feminist Reformulation', Millennium, 17:3, 1988; also Tickner, 'On the Fringes of the World Economy'. The World Human Rights Guide, 3rd edn (New York: Oxford University Press, 1992), compiled by Charles Humana, notes that even in Scandinavian countries and the English-speaking democracies, women are underrepresented in government, earn less than men, and are less powerful in households (pp. 8-9). Figures from the Human Development Reports 1997, United Nations Development Programme (New York: Oxford University Press, 1997) support this. See Table 11, pp. 172-3.

21 See S. M. Okin, Justice, Gender and the Family (New York: Basic Books, 1989); also Diane Elson 'Gender-Aware Analysis and Development Economics', Journal of International Development, 5:2, 1993.

22 Turpin and Lorentzen, The Gendered New World Order, p. 3; also Human Development Report 1997, ch. 3 . 
affects the probabilities of children becoming assets or liabilities to society in later years. Inputs to the quality of nurture include parents' access to housing, health, education and meaningful political participation. ${ }^{23}$

- Women in most countries are the primary managers of household consumption of perishables (food, clothing, medicines, cleaning agents, fuel, water) i.e. nurturing goods, while men retain primary control of the acquisition of durable goods (land, cattle, houses, tractors, trucks, generators) i.e. capital goods recognised by banks as collateral for credit. ${ }^{24}$

- Households are important sites of resource-allocation and political power. ${ }^{25}$

- Most religions hold strong tenets on marriage and family structure, affecting understandings of the roles of women and the socialisation of children. Depending on how these faiths are interpreted, these tenets may either support or undermine the bargaining power of women at home, in public policy debates, and in the market place. $^{26}$

These areas of research strengthen the case for a reworking of IPE theory.

In a pioneering collection, Nash and Fernandez-Kelly showed the unfolding connections between changing patterns of international production and changes in power between classes and genders of workers in different countries. ${ }^{27}$ Contributors demonstrated the place of households in the interdependence of economic production and social reproduction. Later contributions have built upon that, such as Nash and Safa, with reference to Latin America, and Agarwal and others focusing on Asia. ${ }^{28}$

The place of households in the world economy was theorised in another way by Smith, Wallerstein and others. ${ }^{29}$ They examined the responses of households in different parts of the core and periphery of the world economy to upswings and downturns in economic growth. Smith and others found that households change in response to economic conditions and are an important site of resistance to the pressures of the world economy.

Other macro-level Marxist-feminist analysts such as Mitter, and Mitter and Luijken have traced the effects of the feminisation of the labour force in manufacturing in both industrialised and developing countries. ${ }^{30}$ Essentially these show

23 Diane Elson, 'Gender-Aware Analysis'.

24 Human Development Report 1997, ch. 3; Maria de los Angeles Crummett 'The "Women's Movement", in K. P. Jameson and C. K. Wilbur (eds.) The Political Economy of Development and Underdevelopment (New York: McGraw Hill, 1996); I. Palmer, Gender and Population in the Adjustment of African Economies: Planning for Change (Geneva: International Labor Organization, 1991).

25 Joan Smith and Immanuel Wallerstein, Creating and Transforming Households: the Constraints of the World-economy (Cambridge, New York: Cambridge University Press, 1992); June Nash and Helen Safa, Women and Change in Latin America (South Hadley, Massachusetts: Bergin and Garvey Publishers, 1986); and Nash and Maria P. Fernandez-Kelly (eds.) Women and the International Division of Labor (Albany: States University of New York Press, 1983).

${ }^{26}$ For an example of the impact of religion on household and market power in South Asia, see Bina Agarwal "Bargaining" and Gender Relations: Within and Beyond the Household', Feminist Economics, 3:1, 1997.

27 Nash and Fernandez-Kelly (eds.), Women and the International Division of Labor.

28 Nash and Safa, Women and Change in Latin America; Bina Agarwal (ed.), Structures of Patriarchy: State, Community and Household in Modernizing Asia (London: Zed Books, 1988).

29 Smith and Wallerstein, Creating and Transforming Households.

30 Swasti Mitter, Common Fates, Common Bond: Women in the Global Economy (London: Pluto Press, 1986); S. Mitter and A. Luijken, The Unseen Phenomenon: The Rise of Houseworking (London: Change Publications, 1989). 
that the feminisation, automation and mobility of transnational manufacturing have weakened previously unionised (male?) workers in relation to capital. In addition, they point out, full-time workers in manufacturing have also had to compete with out-sourcing from home-based light manufacturing of products like toys and garments. Thus, what on the one hand has been the empowerment of some women through access to jobs in manufacturing, or access to income with control of time for other domestic responsibilities through home-based manufacturing, has, on the other hand, increased the disarticulation of labour solidarity, transnationally and by gender.

Marxist-feminists disagree on the nature of the historical forces behind these patterns. Some, like Mitter, see capitalism as being patriarchal to the extent that this is useful to accumulation. Others like Hartmann, and Mies, see a positive logic of both patriarchy and accumulation at work in modern capitalism. ${ }^{31}$ In any case, these contributions since the 1980's have begun the re-mapping of IPE, with particular reference to macro-level structures and dynamics of production, and the place of households within them.

Fewer of these contributions have focused upon the integration of the gendered analysis of the public and private spheres of production and reproduction with those of war/peace issues, ecological concerns and questions of rights/ideology and authoritative institutions. These respective subjects of concern have tended to be addressed in separate lines of analysis, and in disciplines other than IR/IPE, despite the fact that the connections between them in reality have been recognised. ${ }^{32}$ This has limited the remapping of IPE by feminist scholars.

\section{A complementary IPE discourse}

A discourse has emerged since the 1980s that moves beyond the confines of Realism and what I call 'essential realism' ${ }^{33}$ Other agents in world political economy besides states are recognised, along with their varying motivations, kinds and contents of thinking, power and capacities for creating, modifying and reproducing structures at global, regional, national and local levels. In discussing historical forces such as investment, competition, trade, class conflict or interstate conflict and co-operation, there is an attempt to identify actual patterns of human relationships, without presuming that they are necessarily reproduced in discrete containers of state jurisdiction, nationality, race, or physical geography.

Influential works in this counter-orthodoxy include those by Strange, Cox, and

31 Maria Mies, Patriarchy and Accumulation on a World Scale (London: Zed Books, 1986); Heidi Hartman, 'Capitalism, Patriarchy and Job Segregation by Sex', in M. Blaxall and B. Reagan (eds.) Women and the Workplace: The Implications of Occupational Segregation (Chicago: University of Chicago Press, 1976).

${ }^{32}$ As Turpin and Lorentzen (eds.) have done in The Gendered New World Order.

${ }^{33}$ My critique of Realism and essential realism is contained in 'Politics of Global Industries: Toward New Images of World Politics and World Society', paper to the Northeastern Political Science Association meeting, Providence, RI, November 1988. 
Gill and Law. ${ }^{34}$ Later collections reflecting this influence include Murphy and Tooze, Morgan et al., and Stubbs and Underhill. ${ }^{35}$

Broadly speaking, these have sought to explain the dialectics of firms, financial institutions, classes and states as they integrate four key functions of politicaleconomy: security, production, finance and knowledge.

Strange, in particular, demonstrates the close interdependence of the four functions in what she sees as the four basic corresponding structures of the world economy. ${ }^{36}$ Each of the four structures is constructed and driven to change by several forces. These include agent motivations (order, wealth, freedom and justice), market competition, and technological and institutional innovation resulting from the application of scientific theories and social scientific ideas. Other forces include conflict between structure-makers and structure-takers over the fruits of production, trade and the use of credit, and not least, conflict over control of state policies.

Each dynamic system needs the others. For example, production requires inputs of technology, credit, a disciplined labour force and a context of industrial peace, contractual enforceability and market predictability. ${ }^{37}$ The systems are held together by a succession of bargains among its primary agents at different network levels. These bargains provide a framework of rules for authoritative decision-making until they break down under the weight of changes in power distribution, market fortunes, or value-preferences.

Bargaining frameworks in the security structure have been the most familiarpower-balancing alliances, regional security arrangements, Cold War rules of conduct and so on. ${ }^{38}$ Ordering bargains in the production structure have included cartels, and quasi-cartels among leading firms and their supporting governments in industries like oil and aluminium. ${ }^{39}$ The politically acceptable boundaries of markets have been configured in bargains as varied as GATT, the Lomé Convention, the Common Agricultural Policy, the Multifibre Agreement, NAFTA and the WTO. The bargains that really organise the financial structure are even more decentralised and obscure than the formal ones struck in the interstate contexts of the IMF and the Bank for International Settlements. ${ }^{40}$

34 Strange, States and Markets; R. W. Cox, Production, Power and World Order: Social Forces in the Making of History (New York: Columbia University Press, 1987); S. Gill and D. Law, The Global Political Economy: Perspectives, Problems and Policies (Baltimore: Johns Hopkins University Press, 1988).

35 Murphy and Tooze, The New International Political Economy (see note 6); Stubbs and Underhill, Political Economy and the Changing Global Order; Roger Morgan et al., New Diplomacy.

36 Strange, States and Markets.

37 On the interdependence of the knowledge and security structures respectively, with other structures, see essays by Steven Gill and Barry Buzan in Stubbs and Underhill (eds.), Political Economy.

38 Buzan in Stubbs and Underhill and other work by the same author.

39 I have traced the example of the world aluminum industry, which has moved through several ordering bargains. See Michael H. Allen, Bargaining and Change: The International Bauxite Association, 1973-1977, Ph.D. thesis, London School of Economics, 1984.

40 On the political framing of trade bargains see Victoria Curzon Price, 'The Decay of GATT: Does Multilateralism have a Future?' in Roger Morgan et al. (eds.), New Diplomacy in the Post-Cold War World (London: Macmillan, 1993). See also Miroslava Filipovic, 'A Global Private Regime for Capital Flows', paper presented to British International Studies Association, York, December 1994; and Susan Strange, 'Transnational Financial System of the 1990s', paper for the International Studies Association, Vancouver, 1991. See also Orson Watson, 'The Soros Proposal: Credit Risk Insurance as Global Governance', paper presented at the International Studies Association Annual Conference, Minneapolis, March 1998. 
Other scholars in the counter-orthodoxy also integrate the wide range of IR subjects within an IPE framework. Cox's work explores the mutual feedback effects among the structures of transnational production, the national and public international institutions created to secure and service that production, and the social forces asserting themselves to reinforce or reinvent those relations of production, institutional arrangements, and the attendant rules and ideologies. ${ }^{41}$ Regarding public international authority and rules, Gill sees new developments in regional institutions like the EU as expressions of the contemporary needs of globalised capital. ${ }^{42}$ The globalist and Liberal ideological thrust for juridical protections for property, as the basis for the reliability of market transactions, is consistent with the emphasis on human rights and constitutional government around the world. From a globalist perspective these make practical sense in terms of the security of the environment for investment and trade. In this context, questions about who gets to shape the ideological and theoretical agenda for debate about rights, equity and sustainability become politically important. Thus the politics of knowledge has attracted particularly critical attention in the IPE counter-orthodoxy. ${ }^{43}$

By and large, what seemed like separate subjects in the orthodox paradigms that have dominated IR previously, are naturally integrated in the IPE counterorthodoxy, because the security, production, finance and knowledge functions are regarded as facets of connected historical processes.

This discourse makes a nuanced analysis of the post Cold-War globalised world political economy possible, even as it spawns different models of reality and different visions of a desirable future. It allows different kinds of agents - farmers, workers, bankers, states - perhaps by the mere fact of recognising them, the possibility for analysing the world from their own perspectives without losing a sense of the perspectives and power of others. But there has not been much explicit inclusion of women as specific agents in this discourse.

It is not a big step to take advice from Elson and disaggregate workers into male and female, since they tend to bring different concerns to the search for paid employment. ${ }^{44}$ As Standing shows in her analysis of the feminisation of global light manufacturing industries, the bargaining power of women workers for wages and job security is generally much weaker than that of men..$^{45}$ The contributions of Nash and others, and Mitter and others would show that bargaining power has changed by gender, geography and class as a result of the technological sophistication, global mobility and feminisation of the production structure in recent years. ${ }^{46}$ This analytical change would certainly enrich the understanding of agency

${ }^{41}$ Cox, Production, Power and World Order. See also R. W. Cox, 'Social Forces, States and World Order: Beyond International Relations Theory', in R. O. Keohane (ed.), Neorealism and its Critics (New York: Columbia University Press, 1986).

42 Gill and Law, The Global Political Economy; also Stephen Gill, 'Global Macro-economics and the Internationalization of the State: Regulating the Power of Capital'. Paper presented at the British International Studies Association Annual Conference, Warwick, England, 1991.

43 This is reflected in renewed interest in the thought of Gramsci and of Kant. See Randall Germain and Michael Kenny, 'International Relations and the New Gramscians', and Wade L. Huntley, 'An Unlikely Match? Kant and Feminism in IR Theory' (see fn. 9).

44 Diane Elson, 'Gender-Aware Analysis and Development Economics', Journal of International Development, 5:2, 1993.

45 Guy Standing, 'Global Feminization Through Flexible Labor', World Development, 17:7, 1989.

46 Mitter and Luijken, The Unseen Phenomenon; Nash and Fernandez-Kelly, Women and the International Division of Labor. 
and power in the world production structure as conceived by Strange and others, and inform my own analysis of global rivalry among workers and the bargains they can and cannot make with firms. ${ }^{47}$

I carry over the Marxian notion of modes of production into this discourse, by suggesting that there are four main modes in the contemporary world economy. These are the global, national capitalist, informal (mostly urban) and subsistence (mostly rural) modes of production. The key functions of security, finance, production and knowledge have to be applied in all of them, and they comprise different mixes of capital-labour inputs, class and ethnic configuration/conflict, and degrees of market competition. ${ }^{48}$ The richest in capital, knowledge and organisational assets is, by far, the global mode, followed by the national capitalist. Generally speaking, informal and subsistence activity is associated with poverty, except in the case of illicit drug trade. As the research of feminist economists already cited shows, women figure prominently in subsistence and informal production, much less so in national and global modes of production. Where they do get recruited into these as workers, it is on very unfavourable terms and at generally low levels of remuneration and decision-making authority. ${ }^{49}$

Even with these changes, analysis using the four fours (four functions, four modes, four values, four primary agents) does not get to the heart of the problem that women face as contributors to the world economy. It is the old one, that if particular women accept the responsibility of childbearing and nurture, they must either find ways simultaneously to support themselves and their offspring, or depend in whole or in part upon partners, extended families, charities or states. To forestall the powerlessness of dependence, they must have access to means of power and production like education, land, equipment and credit. If the rules and values in the cultures in which they live constrict their rights of inheritance, control of reproduction, and control of time (for paid or unpaid work ), their basic needs and those of their dependants are likely to be inadequately met. This problem is obviously greater in the informal and subsistence modes of production where partners and extended families, as potential sources of subsidy to women's incomes, are themselves relatively powerless in terms of land, capital, knowledge and credit.

Women as nurturers have to ensure domestic consumption. Single women with few prospects for inheritance or without high levels of education, must ensure their own support. Thus, both mothers and single women without children may have reasons to enter the job market at very low wages, motivated by a logic of security of consumption rather than that of the maximisation of returns on effort. So the household as a site of political-economic resource-allocation and bargaining is a necessary addition to new IPE descriptions of context. With the household as level of analysis, we are forced to look at the difference women's participation makes to structures, and at differences in motivations for economic and political participation. Assumptions of rationality and universal motivations will not provide satisfactory explanations.

47 Allen, 'Rival Workers' (see fn. 4).

48 Political economy in South Africa demonstrates this mix, as I argue in 'Bargaining Dynamics of PostApartheid State: Market, Class and Ethnic Dimensions', in Paul B. Rich (ed.), The Dynamics of Change in Southern Africa (London: Macmillan, 1994).

49 The UNDP Human Development Report 1997 shows in its gender empowerment measure that women's roles in administration and management, professional and technical occupations and shares of earned income are still well behind those of men in all categories of countries. Table 3, pp. 152-4. 


\section{Bargaining in households and basic IPE structures}

The explicit inclusion of households as a subject of analysis in IPE draws attention to nurture/reproduction as a fifth basic function of political economy. While this has been explicit in feminist economics and implicit in the new IPE discourse, it is useful, both in terms of analytical elegance and the counter-hegemonic politics of knowledge, to make it explicit in the emerging synthesis, with the same status as security, production, finance and knowledge.

Moreover, authoritative decision-making in terms of rules, and the construction of meaning, values and identity are distinct political-economic functions that give rise to networks of relationships, and influence the evolution of the security, production, nurture and other structures. ${ }^{50}$ All seven are at work in households as much as they are in markets, public institutions and interstate encounters. ${ }^{51}$ For present purposes, the argument is developed with respect to households.

Some of the most important decisions that affect the degree and content of demand in the world economy are made in households. Even infants and children are consumers, and in some countries, focused marketing is directed at them directly or through their caregivers. Significant aspects of lifestyle are expressed in households, even as these are themselves shaped by beliefs, ideas and values emanating from other sources such as popular media and religious communities. Lifestyles are further constrained or facilitated by levels of income or subsistence activity. Households are where human energies are replenished for the workplace and the market. They are the places where new cohorts of workers, professionals, entrepreneurs and citizens are produced and the first stage of the investment or disinvestment in their emotional, ethical and intellectual capital. Where this is done well and at low costespecially as it is subsidised by women's labour in worker nurture, childcare and subsistence farming - it lowers the cost at which both women and men can come onto the formal labour market. This is consistent with the interests of firms in both the national capitalist and global modes of production, and with the policy needs of states that pursue strategies requiring competitive wages.

So, women's nurturing labour subsidises the formal economy by making male and female workers productive and firms and states competitive. But women are paid

50 While legal scholarship and jurisprudence are clearly part of the knowledge structure, rules and the everyday practices that operationalize them are as distinct from legal scholarship as shopping is from economic theory. Rules both shape and reflect what is acceptable behaviour in markets and institutions of authority. In most complex social formations, the relations of authoritative decisionmaking are as distinct as those of production, finance or advanced knowledge. The relations of meaning and identity-construction (religion) are also usefully seen as distinct. In premodern times these shaped the relations of production, finance, knowledge and authoritative decision-making more than they do now. With the perceived failure of modernity in many parts of the world there are revised attempts to make religion the basis of political-economic coherence, many times, at the expense of women. See Mark Jürgensmeyer, 'The Worldwide Rise of Religious Nationalism' in Journal of International Affairs, 50:1, Summer, 1996. See also N. J. Demerath III and Karen S. Straight, 'Religion, Politics and the State: Cross-Cultural Observations', in Cross Currents, 47:1, Spring 1997.

51 I place law and order in distinct domains because in any social context, those who hold legitimate decision-making status are not necessarily also the ones who can assure order. People in countries with powerful counter-elites like drug barons or corrupt soldiers know this well. Those whose power to coerce must be taken into account, despite the rules, are part of the security structure. At the level of households, if laws against spouse abuse are absent or not enforced, the victim partners have both a security and a nominative problem. 
only as dependants or when they enter the market themselves as workers or traders. The resulting exploitation can only be eradicated if men put more time and energy into nurture, and firms and states either reward men for doing so, subsidise the cost of nurture, encourage women to enter the marketplace during their most productive (and reproductive) years, or all of the above. ${ }^{52}$ The greater inputs of active fathering would both enrich the quality of life and strengthen the investment in the preparation of the next generation. For this to occur there would have to be changes in the power of women in relation to men within the household, and in relation to firms and states. There would also have to be changes in the thinking and values of men, in the paradigms of personnel management (in firms), and macro-economic management and IPE (in states).

Some of these changes are occurring. Trends in American and European law and in company practices have made it easier for women or men to balance nurturing and workplace responsibilities. Especially in high-skill labour markets, companies increasingly regard easing the nurture/production tension as good investment. ${ }^{53}$

Households have become even more important sites of decision-making in the world economy following the adoption by states of the free trade norms of the Uruguay Round and the WTO rules. States have given up much of the right to be gatekeepers of their domestic consumer markets, in exchange for the chance to have greater access to the world market for firms in their own jurisdictions. Any nationalist consumption strategy which gives preference to local producers will largely have to be articulated at the level of households. This is a tremendous opportunity for women, to the extent that they primarily manage household consumption, to increase their bargaining power with states, over the terms on which nurture and reproduction are delivered to the macro-economic mix. The change in the legal or formal authority structure has created an opening for change in other structures. In the context of such bargaining, states and public international agencies like the IMF, IBRD and WTO might be induced to act more concertedly upon the knowledge that the poverty and powerlessness of vast numbers of women in the world economy undermines their capacity to make the human capital investments from which everyone-not least states and firms- benefits. $^{54}$

Negotiating a new relationship requires not only a change in the distribution of opportunities to exercise power but also a change in consciousness, without which these opportunities may pass unnoticed or may not be perceived as desirable. ${ }^{55}$

This returns us to the question of socialisation and notional influence. Most women and men are influenced most immediately by the world views and ethical

52 The Swedish state has attempted to do much of this with mixed results. See Anna Nelson 'Sweden: Equality and Difference in the Labor Market and in Family Policy', Senior Thesis, Bryn Mawr College, April 1996. See also Maud L. Eduards, 'Toward a Third Way: Women's Politics and Welfare Policies in Sweden', Social Research, 58:3, 1991.

53 See Hal Morgan and Kenny Tucker, Companies that Care (New York: Simon and Schuster, 1991).

${ }^{54}$ It is true enough that IMF functionaries are aware of these connections as evidenced in their publications, such as: Paul Gleason, 'Poverty Reduction and Structural Adjustment discussed at IMF Seminar', pp. 178-82, IMF Survey, 22:12, June 14, 1993, International Monetary Fund, Washington DC. However, the practical effects of IMF-imposed adjustment requirements, specifically for women in developing countries, remain in tension with the spirit of such publications. On these practical effects, see Mary J. Osirim, 'The Dilemmas of Modern Development: Structural Adjustment and Women Micro-entrepreneurs in Nigeria and Zimbabwe' in Turpin and Lorentzen (eds.), The Gendered New World Order.

55 I demonstrate this point in Bargaining and Change (see fn. 39 above). 
systems of their local cultures rather than by the scholarly theories and formal ideologies emanating from universities, public agencies, even NGOs. For the most part, this means religious communities, family ties, school systems and popular culture. Even for this reason alone, it seems to make sense to regard systems of meaning and values (both formal and informal) as having a dynamic impact in the world economy distinct from that of the scientific and technical knowledge structure. Marxist, Gramscian and other radical theorists have tended to lump these two, together with law, as 'ideological production' but this will no longer do. We cannot talk about households as IPE context, or about nurture/reproduction as basic IPE function, without reference to the relations of meaning and value identification, or reference to the structure of rules that constrain or reflect the behaviour of their key agents. ${ }^{56}$

These normative systems, and the institutions and social ties which foster them, shape how women and men understand their mutual obligations as well as those to companies, and states. At some moments these norms make people uncomfortable with their real actions in these relationships. The moments of discomfort are opportunities for reflection and possible renegotiation of prior relationships.

The impact of the power to interpret religious tenets in ways that either restrict or emancipate women, is demonstrated, for example, in essays by Nahid Toubia and others. ${ }^{57}$ They show that in several Arab countries, resurgence in religious conservatism in the 1980s meant retrenchment of women's social and economic freedoms. Their capacities to organise and resist on a religious front, nationally and transnationally, have in turn been limited institutionally and legally by states in whose jurisdictions they live. While women's own experiences, plus contact with advanced knowledge through education (for some), have led to a desire for change, the capacity to act in any one sphere is limited by constraints in others. Voices from other parts of the world also show that religion is a frontier of ethical struggle where issues of household and market, productive and reproductive power are at stake. ${ }^{58}$

Law (rules, authoritative decision-making procedures and their philosophical justifications) is a reflection of configurations of power, and an indicator of the relative strengths of competing ideologies in any given context. ${ }^{59}$ As such, law is a domain of struggle between cultures, genders, classes, nations and modes of production. At present, those who hold power in the global mode of production are mainly Western and Judaeo-Christian and are succeeding in renegotiating prior structures of law around the world. This is evidenced in treaties for trade and investment liberalisation and in the internationalisation of authority in treaty-based institutions such as EU, NAFTA, WTO, and UNCLOS. The authority of territorial

56 This dialectical understanding of law or authoritative decision-making in the context of real politicaleconomy is well demonstrated in the work of Richard Falk in International Law. See Richard Falk, 'An Inquiry into the Political Economy of World Order' in New Political Economy, 1:1, 1996.

57 Nahid Toubia (ed.), Women of the Arab World (London and Atlantic Highlands, NJ: Zed Books, 1988).

58 See Diana L. Eck and Devaki Jain (eds.), Speaking of Faith: Global Perspectives on Women, Religion and Social Change (Philadelphia: New Society Publishers, 1987).

59 I draw this understanding of law from the work of Richard Falk, as in The Status of Law in International Society (Princeton: Princeton University Press), 1970, Part I. As he and others who take a Social Science approach to International Law point out, law is not always relevant, since those whom legal logic and juridical standing favour are not always the ones who have coercive power to deliver or disrupt order. This points to the usefulness of regarding the security and authoritativedecision-making structures as distinct in world politics. 
states has given considerable ground through negotiation to the new forms of transnational, transgovernmental, international and supranational authority. ${ }^{60}$ What remains of state authority is under globalist pressure for democratic reform.

To the extent that the feminisation of the production structure has been an important element in the globalist strategy to foster competition among workers, globalist and feminist agendas have coincided on the question of women's access to the marketplace. At the same time, feminists have run into opposition on questions of law and rights from those guardians of national capitalist and other territorially or culturally-specific modes of production, who in resisting globalist penetration, also reject its feminist and other democratic elements as being Western and/or Judaeo-Christian. ${ }^{61}$ So, at present, both globalisation and economic/religious nationalism are contradictory historical processes, both containing emancipatory and oppressive elements. In some instances, the rearguard action of cultural nationalists has led them to adopt positions that are less respectful of women's rights than their own states had adopted, or acquiesced to, in the United Nations in the post-war decolonisation period. ${ }^{62}$

Certain categories of rights were defined and sharpened in the Cold War and decolonisation debates. Competing camps that drew on different philosophical traditions were forced to put their best principles forward for strategic reasons, even if they were not yet ready to implement them at home. Nonetheless, normative seeds sown in a state-centric strategic agenda in one context, have grown up to be harvested by other agents in the world economy in a different context.

Thus, the history of debates and resolutions within the UN system on questions of Human Rights, development, labour standards, women's rights and the rights of children have produced formal principles which are ahead of the current practices of most states, firms, religious communities and households, in terms of justice for women. ${ }^{63}$ So while authoritative institutions and rules lend normative support, and in some instances may even be justiciable in municipal and international courts in the cause of women's rights in the household and in the marketplace, the inertia or outright resistance of those who hold power in terms of physical security, investment, credit and religious loyalties must still be overcome.

To sum up, feminist contributions have further shifted our prior images of the structure of world society. We are forced to break out even further from the earlier focus upon the tight cluster of agents such as states, firms, and interstate institutions. The new IPE discourse had already included workers, farmers, and marginal groups

60 There is an emerging discourse on new forms of authority in international political economy. On transgovernmental trends see Anne-Marie Slaughter, 'The Real New World Order', Foreign Affairs, September/October 1997; on transnational forms of authority see Susan Strange, The Retreat of the State: the diffusion of power in the World-economy (New York: Cambridge University Press, 1996). On nascent supranationalism, see again Gill, 'Global Macroeconomics ... .' (see fn. 42 above).

61 See again Nahid Toubia (ed.), Women of the Arab World.

62 It is helpful to remember that the Universal Declaration of Human Rights of 1948 was supported by a wide cross-section of states from all regions and religions of the world, albeit after much caution and equivocation on the part of some delegations. This contrasts with some nationalist protests since then, that universal minimal standards are impossible, or are necessarily expressions of Western hegemony.

63 For example the Universal Declaration of Human Rights, which speaks of 'the equal rights of men and women' dates back to 1948; the 'Convention on the Political Rights of Women, 1953' entered into force in July 1954; and the 'Declaration on Elimination of Discrimination Against Women, 1967' was adopted unanimously by the UN General Assembly in November 1967. 
outside of formal capitalism. Scholars in Peace and Conflict Studies had already pointed to the importance of religion and other sources of ethnic identity-formation, as factors in local and regional conflicts. The links between persistent conflict and market disruption and postponed development are well-established analytically ${ }^{64}$ Thus the social formations created by religious affiliations were already becoming part of the disciplinary concern in IPE. But feminist scholarship on the household calls into specific focus the gendering effect of religion and popular culture upon bargaining power within the household, upon the limits or possibilities created by legal rights, and upon local and, eventually, transnational divisions of labour. ${ }^{65}$

In adding legal and religious/popular-cultural formations to the networks of agencies recognised in IPE, we may do so in ways that explore their impacts not only upon identity and aesthetics, influencing market and juridical boundaries, but also upon which genders get what, when and where, in familiar local, national and global political economy.

\section{Prospects for new gender bargains}

Women need a new deal with men in households, with banks for recognising new forms of creditworthiness, and with firms and public service institutions for valuing the perspectives they might bring to management at all levels. Women seem to be getting a new deal with states in developed countries, and intergovernmental agencies like the IMF. Public expenditures and legislation on childcare, family leave (for women and men), health (including reproductive health and family counselling) have come to be more widely recognised as sound macroeconomic and political-risk investment. ${ }^{66}$

These postures of some states are a reflection of the extent of their embrace of globalist agendas. There are active debates within IGOs on the political economy of development. However, even the IMF, previously known for its neo-liberal rigour, has in recent years come to state the need for empowerment strategies. ${ }^{67}$ This is so in spite of the unfortunate practical effects for women, of its adjustment requirements in developing countries. As one of the premier institutions that facilitate globalisation, the IMF could be expected also to reflect that element of the agenda that encourages the feminisation of markets. So the question is whether the gendering of the agendas of transnational firms, globalist states and public international institutions reflects an extensive or strictly limited commitment to women's empowerment.

64 See again Turpin and Lorentzen, The Gendered New World Order; see also Johann Galtung, Peace by Peaceful Means: Peace and Conflict, Development and Civilizations (Oslo: International Press, Research Institute, 1996).

65 See again Agarwal " "Bargaining" and Gender Relations: Within and Beyond the Household', Feminist Economics, 3:1, 1997.

66 The Clinton administration in the United States has strongly advocated family leave and other legislation that reflects awareness of the connections between household economies and the market economy.

67 See for example David Cheney, 'Conference Addresses Major Issues Relating to Global Poverty', IMF Survey, 22:3, February 8, 1993. 
The humanising effects for some women in some parts of the world economy could be an end in itself or the fortunate by-product of more pressing concerns.

The latter seems to be the case, because this moment of choice in the world economy is like earlier ones involving powerful interests and powerful principles. These included: the slave trade debate and treaty negotiations at the turn of the nineteenth century; slavery itself in the first half of that century; workers rights and unionism thereafter; choices on the rights to self-determination of peoples living under colonialism and apartheid following the two world wars; responses to the economic nationalism of the late 1960s of states whose minerals like oil, and bauxite were wholly owned by multinational corporations; responses to those same states in the 1970 s as they jointly protested the unfairness and economic dysfunctionality of the Bretton Woods Order; and responses of nuclear states to non-nuclear ones in the 1980s about the arrogance of a nuclear game exclusive to the nuclear powers that had consequences for all peoples.

In all of these moments the question was whether principles, derived from common conceptions of humanity and justice-jus cogens-would prevail above interests as defined then by the key agents who held power in the structures of the world economy. Their lessons are not encouraging.

To select a few, the British could afford to agree to end slave trading in 1807 because labour needs in the West Indies were changing in the face of new plantation technologies and the reproduction of resident slave populations. They could even police the West African coast against slaving since they now had an interest in having trading competitors not undermine the climate for new kinds of alliances and trade with West African states. ${ }^{68}$ Similarly, slavery itself could end because new approaches to production became more viable. ${ }^{69}$ Apartheid could be abandoned because a critical mass of the Afrikaaner elite had outgrown its dependence on incumbency in the state apparatus and had become more capitalist than racialist. ${ }^{70}$ Nationalisations and joint ventures by host states in the 1970 s, were eventually accommodated by companies and their home governments because the latter had secured new ways of getting raw materials and controlling world markets in metals and minerals industries. ${ }^{71}$ Enlightened self-interest seemed about to be given a chance by rich states in the North-South negotiations of the late 1970s in a kind of international Keynesian new deal, since their own economies were not realising adequate growth. ${ }^{72}$ The whole venture was scuppered by the victory of supply side administrations and doctrines in key states in the North. Self interest did not so much compete with principle-it became the principle, complete with its own moral justifications in the name of efficiency and individual responsibility for economic outcomes. Bargains to reduce the number and categories of nuclear weapons as well as harmful techniques of testing could be reached when the number and quality of

68 This is the thrust of Eric Williams' thesis in Capitalism and Slavery (New York: Capricorn Books, 1966).

69 Williams, Capitalism and Slavery.

${ }^{70}$ Michael Allen 'Bargaining Dynamics of a Post-Apartheid State' (see above fn. 48).

71 An example of this is found in the case of aluminum. See Allen, Bargaining and Change (see fn. 39).

72 This was a major argument of the two Brandt Commission reports: North-South: A Program for Survival (Cambridge: MIT Press, 1980) and Common Crisis, North-South Co-operation for World Recovery (London: Pan Books, 1983). 
the weapons systems threatened the economic and military security of the states involved and when new technologies of testing had already been found. ${ }^{73}$

The entry of Liberal feminist concerns - treating men and women the same in the public sphere-to the mainstream of ideas and public policy in the industrial democracies, and their spread to other political spaces where global production, trade and legal rules are taking root, occurred when it was consistent with the interests of transnational firms. ${ }^{74}$

It would seem that in every instance, any victory for principle had to await its coincidence with new interests of the powerful. Further bargaining on the principle of fairness to women would seem to require a redefinition of self-interest among those who now hold power, in addition to the mobilisation of women's own increments of power in households, congregations, markets and states.

A cynic might conclude that only Pyrrhic victories are possible in such moments of negotiation in political-economy, that processes of domination move on to new structures and techniques, leaving empty human gains in their wake. While this is to some extent true, the advances beyond slavery and so on are also genuine, and a quotient of justice is extracted at each paradigmatic shift.

To be sure, principles of justice have shaped the actions of a significant number of persons more powerfully than immediate self-interest, in every one of the struggles just mentioned. Some planters objected to slavery on principle and acted upon their convictions. ${ }^{75}$ Many Afrikaaners in South Africa gave up careers, social acceptance and even freedom for the cause of non-racial democracy. ${ }^{76}$ The new post-apartheid state gave up nuclear weapons on principle, despite the regional and global prestige attached to their possession. ${ }^{77}$ Many men accept a slower path in their careers in order to contribute to nurture and homemaking. But such actions against the prevailing norms require a transformation of consciousness that seems to arise only in a small minority of persons. ${ }^{78}$ For the most part, people are for or against change for reasons of practical interest, and apply their powers of reason, wealth and force to that end.

Marx had already recognised that the powerful protect their interests through ideology. Mannheim agreed but warned that even revolutionaries are mere 'utopians', disguising self-interest in change with visionary universal principles. ${ }^{79}$ Weber had noted that social agents adopt and interpret ideas in ways that are consistent

${ }^{73}$ Undersea and atmospheric tests of nuclear warheads could be systematically banned between 1963 and 1974 largely because the major nuclear states had, by then, invented underground testing. France, which lagged behind in this technology was slower to stop than the US and USSR. A useful backgrounder remains Common Security: A Programme for Disarmament, Olaf Palme and others (London: Pan Books, 1982).

74 See again S. Mitter (see fn. 30).

75 On Jamaican instances, see Aggrey Brown, Color, Class and Politics in Jamaica (New Brunswick: Transaction Books, 1979).

76 The example of Beyers Naude comes to mind. See The Trial of Beyers Naude: Christian Witness and the Rule of Law edited by the International Commission of Jurists (Geneva and London: Search Press in conjunction with Rovan Press, Johannesburg, 1975).

77 See Mitchell Reiss and Robert Litwak (eds.), Nuclear Proliferation After the Cold War (Washington DC: Woodrow Wilson Centre Press, Distributed by Johns Hopkins University Press, 1994), particularly the chapter on South Africa by David Fischer.

78 I raise this point as a question of critical reaction to Manfred Halpern's theory of Transformation in 'Politics of Global Industries'.

79 Karl Mannheim Ideology and Utopia: An Introduction to the Sociology of Knowledge (London: Routledge and Kegan Paul, 1936). 
with their interests whether for or against change. ${ }^{80}$ While these make a strong case for the continuing relevance of this kernel of realism, the explanations of social and institutional change in any of the examples cited cannot properly be made without taking account of the catalytic influence of persons who were moved by a form of consciousness that is a step above the rational self-interest recognised in Realism. Power applied in self-interest is a valid historical postulate, but not the only one. History is as much about Mandelas as it is about Malans. ${ }^{81}$

Therefore in assessing the prospects for renegotiating women's relationships at the respective levels of political-economy, we must be open to the possibilities for new forms of consciousness among those who now hold power and privilege, while being realistic about the need for struggle in terms of power.

The negotiations to be undertaken are interdependent. Men will not contribute more at home in large numbers unless popular culture and/or religious convictions encourage them to do so and/or unless women get to earn more in their own right. ${ }^{82}$

To this end, theological engagement in religious contexts, and popular dialogue through the arts and mass media are critical to gender bargaining both at home and in markets and public institutions. Theoretical and factual engagement in the knowledge structure are vital in expanding the mental horizons of bankers and public agencies which make decisions about the feasibility of lending to women, or financing social programmes which empower women at home and in markets. ${ }^{83}$ The mobilisation of women voters draws debates and decisions on public expenditures and legislation in the direction of women's concerns. Even in countries without a meaningful vote, the legitimacy of regimes can be fostered or undermined by the attitudes to them of women who are organised. The protests of mothers of the disappeared in Argentina during the military dictatorship of the 1970s and 80s are eloquent testimony to this. Women can get and keep the attention of companies and states by what they organise not to buy in terms of consumer goods. The deal can be: treat us right in the workplace and we'll treat you right in the supermarket. In the contexts of civil and regional wars, women can open their own dialogues across lines of conflict and offer alternate approaches to disagreement and negotiation. If this can be presented to men and states on their own sides as routes to security and economic growth, it would at once empower the women of those regions and aid social and economic development. Where the propensity to address conflicts by use of force feeds on local values which see that as honourable and heroic, women can respond by valuing a different image of desirable masculinity. Guerrilla fighters

80 A helpful interpretation is offered in the chapter on Max Weber in Lewis A. Coser, Masters of Sociological Thought (New York: Harcourt Brace Jovanovich, 1977).

81 This refers, of course, to two contrasting figures in South African history, with Mandela seeming to have gone against the grain of immediate self-interest for the sake of social justice. Realism and idealism are not dichotomous, but dialectical. For a sceptical view, see Roger D. Spegele, 'Is robust globalism a mistake?', Review of International Studies, 23:2, 1997.

82 Studies in both developed and developing areas have shown that women's negotiating authority within households increases with their independent earnings. See Philip Blumstein and Pepper Schwartz, American Couples: Money, Work, Sex (New York: William Morrow, 1983), esp. pp. 53, 77 and 164; also Bessie House-Midamba and Felix K. Ekechi (eds.), African Market Women and Economic Power: the Role of Women in African Economic Development (Westport, CT: Greenwood Press, 1995).

${ }^{83}$ Micro-lending on the Grameen Bank model has proven useful in empowering poor women in different regions of the world. Both state and non-governmental sources of funds have been vital catalysts. See for example 'Women in Africa's Development: Overcoming Obstacles, Pushing for Progress', Africa Recovery, (United Nations Department of Public Information: Briefing Paper no. 11, April 1998). 
could then begin to run out of girlfriends and would have to make choices literally between love and war.

Two notes of caution are needed.

One is that the goods at stake comprise different mixes of intellectual, emotional and material elements in the seven systems of political economy. In the knowledge, meaning and law structures much of the currency of power is cognitive-words, images, ways of understanding - even though they have deep implications for material and emotional resource-allocation. Mobilisation and bargaining on these fronts carries grave challenges and even penalties, but is not prohibitively expensive in energy and money. ${ }^{84}$ By contrast, the currencies of power in the production, finance and security structures are more directly material, and male incumbency is deeply entrenched in patterns of ownership and control. Negotiating change in these material systems runs into stiffer resistance and is costlier to mobilise and sustain. Translating gains in the knowledge, meaning and law structures into gains in the production, finance and security structures will largely depend on access to organised shares of state power, and even better organised control of consumer spending. ${ }^{85}$ In households the good at stake is as much affective as material. Even in countries where men and the state have moved on to enlightened self-interest in the empowerment of women, actual change in domestic bargains lags behind the provisions of legislation and the pronouncements of popular discourse. ${ }^{86}$ Even in Sweden, with its post-war history of gender equalising ideology and state policies for the marketplace and household, men's contribution to unpaid labour in the private sphere has not nearly matched that of women. ${ }^{87}$ This was so while Swedish women were approaching the highest percentage of earned income in relation to men (45\%) in any country, and the highest rates of representation in parliament $(40 \%)$, administration and management (39\%), and professional and technical occupations $(64 \%) .{ }^{88}$ This suggests that gender bargaining in the nurture/reproduction structure will in most instances follow rather than lead those in states, markets and congregations.

The second note demands a section of its own.

\section{Rival women}

There should be no illusions that gender solidarity among women will be any more impregnable than that among workers generally in their struggles with companies, developing states in their bargaining with transnational corporations, colonised peoples in their resistance to imperialism, or even abolitionists in their fight against slavery. At moments of heightened engagement in each wave of the human surge for justice, there has been the temptation for the emergent side to see in its project the

\footnotetext{
84 The price to be paid may include ostracism or excommunication in the religious structure or promotion, tenure and research grants denied in the knowledge structure.

85 I have argued that despite the loss of state power in relation to capital, access to state power is critical to bargaining power for workers in 'Rival Worker' (see fn. 4).

${ }^{86}$ See Nelson 'Sweden: Equality and Difference' (see fn. 52).

87 Eduards 'Toward a Third Way' (fn. 52).

${ }^{88}$ See Human Development Report, UNDP, 1997, Table 3, p. 152.
} 
embodiment of virtue. Little acknowledgement is given to the pragmatic urgency and even cynicism that lurk among many on one's own side as reasons for supporting a project for change. But disappointment follows when allies accept deals with those who resist change, exposing narrower interests at the expense of the transformation of larger systems of relationships. Worse, many become what they once opposed when they come into their kingdom. Issues of gender justice are at a moment of heightened engagement and much of the rhetoric is all too familiar. ${ }^{89}$

Not least among barriers to solidarity among women are divisions among them by mode of production, class, market competition and ethnicity. Women of the same class in the global mode of production compete for jobs when transnationals shift from high-wage to low-wage locations. Women in national capitalist production (or who aspire to it), and in state bureaucracies, compete with women who produce and sell in informal activity and/or in subsistence farming for influence on state policy and for access to new forms of credit. ${ }^{90}$ It is not unusual for women with careers in the formal economy in urban areas of the developing world and the suburbs of the developed world, to circumvent the nurture versus career problem by hiring poor(er?) women 'from the country' or from marginalised ethnic groups. ${ }^{91}$ Ultimately, the pool of women and men seeking jobs, loans and market share is usually larger than the available opportunities at any level of the world economy. The resulting competition makes solidarity tenuous at the best of times. Additional factors such as the social distance of status/lifestyle, ethnic insularity, and geographic/communications inaccessibility only make solidarity more difficult. Add to these, strong differences among politically attentive women on questions such as reproductive rights and public benefits for poor women, and we have the picture of a divided agenda. This affects gender bargaining with states on the design of public legislation, and that within religious and popular contexts on the ethics of specific elements of empowerment for women.

Essentialist feminism suggests that women are naturally closer to values of interdependence and mutual welfare than men because these flow out of the imperatives of nurture. This would lead us to expect that women would demonstrate more solidarity than men in the public sphere. This analysis suggests that even if this were true in particular cultures, women's solidarity does not cross class and ethnic lines very well. ${ }^{92}$

By and large, women with greater education, social networks and access to communication and political influence, increase their gains in the marketplace and at

89 One is reminded of the utopian speeches coming from revolutionary movements and governments in the Non-Aligned Movement and UN General Assembly in the 1970s, or from radical social movements of the $1960 \mathrm{~s}$.

90 See Mary J. Osirim, 'Vehicles for Change and Empowerment: Urban Women's Organizations in Nigeria and Zimbabwe', paper presented to the NGO Forum on Women '95, Huairou, The People's Republic of China, August 30 to September 8, 1995.

91 It seems ironic that what women need to do in order to advance in the market place, with all the benefits to society that that implies, may require more time out of households and thus, more time by other women in those same households. The commoditisation of nurture displaces still other women of a different class from nurture in their own families, and marginal compensation does not always match marginal effort or social cost.

92 This points to the idea of different feminisms in a different way, that is, varieties bound by class and ethnicity. In any case, contrary to Essentialist expectations, gender does not predict pacifism and solidarity for women. See Mark Tessler and Ina Warriner, 'Gender, Feminism and Attitude Toward International Conflict: Exploring Relationships with Survey Data from the Middle East', World Politics, 49 (January 1997), pp. 250-81. 
home faster than do women without these advantages. These gains are not easily shared with others across class lines. Legal gains of a non-distributional nature (rights and freedoms, as against benefits) that are spearheaded by elite women can, by contrast, apply to poor women in given countries. The more feasible bargaining solidarity for gains in the legal system is not easily transferred to struggles where redistribution of tangible benefits is involved. But to the extent that the majority of the world's women are engaged in informal and subsistence economic activity, this leaves untouched most of the people and most of the challenges of contemporary world political economy.

In short, gender bargaining will show results in the households, markets and public institutions of the global and national-capitalist modes of production far more quickly than they will in those of the informal and subsistence modes. It suggests the primacy of market and class dynamics over gender in shaping the fate of the majority of the world's women.

\section{Implications}

The foregoing analysis suggests that gender does not confer special insights on justice or human solidarity. Women, like men, express a range of forms of consciousness and bargain in pursuit of them. In some cultures, patterns of socialisation might produce attitudes of cooperative self interest more among women than among men. But the analysis also suggests that the reality of women's experiences of marginalisation in the world economy and victimhood in war, which makes them a class in themselves, does not by itself lead to consciousness of the need to oppose the causes of that marginalisation and violence. Common fates do not necessarily lead to common bonds. ${ }^{93}$ While the core issues of world political economy are gendered, they are also more immediately configured in terms of classwithin-mode of production and ethnicity.

Women's gains in recent years in access to labour markets, with associated legal rights and care/career support, have been facilitated by their consistency with the needs of firms that have to compete in global markets, and with the attendant policies of the most powerful states and IGOs. Women who are upwardly mobile in national or global capitalism are not likely to go much beyond Liberal feminism. Liberal feminism has become a feature in the human face of capitalist ideology. But even in its Radical or Essentialist expressions, feminism is a reforming force in world society, and not a revolutionary one. Its potential for solidarity, whether derived from values of nurture and interdependence, or not, is not greater than the market competitive and class divisions fostered by global or national capitalism, or the chasms of ethnicity and emotional distance. Radical movements, feminist or not, cannot transform global capitalism, but might redirect it. ${ }^{94}$ Women's solidarity may not smother ethnic conflicts, but could make them less violent.

The primary division in contemporary world political economy is between the classes-women and men together-who want to go with the flow of globalisation

93 An allusion to Mitter's book entitled Common Fates, Common Bond.

94 This was an argument in Allen 'Rival Workers'. 
and those who do not, or cannot. To that extent, different feminisms point women in different historical directions, sometimes empowering them to join men in projects of coercion and control. ${ }^{95}$ Women's empowerment changes the public/private sphere bargains within modes, but not necessarily between them.

Liberal and Essential feminisms are quite adequate for limited reform. Critical approaches go beyond this to try to change the bargains between classes in the global mode and others outside it where most women live, from a win-lose to a winwin basis, and try to reduce violence as a technique of conflict. ${ }^{96}$

Empowering women among the poor majority of the world's population cannot be separated from wider strategies of sustainable development, human rights and conflict-resolution.

\section{Conclusions}

Both new discourses and feminist contributions are changing IPE to become a more widely-focused and better integrated field within IR. The core concerns have shifted and the boundaries of analysis have been expanded. Questions of war and peace, ecology and sustainability may be problematised in their related contexts of market, class, ethnicity and gender.

Bargaining can be a valuable organising concept around which to integrate the analysis of complex dynamics of market, class and gender. By expanding the universe of functions that are recognised in IPE to include nurture/reproduction, and the construction of meaning, values and identity, the nature and implications of women's contribution to the world economy can become apparent as a matter of course.

Social change for greater justice is the product of both organised power and moral enlightenment. On matters of gender, the prospects for change by way of organised power are limited, but change can be hastened by new ways of thinking in the several systems of the world economy. The complementarity of organised power and moral debate is likely to produce results faster for women in formal economic activity across the world. New gender bargains in global and national capitalism may reform the terms of women's participation in those markets and their governing institutions. However, they may not necessarily also overcome the basic problems of poverty and ethnic conflict that affect the fortunes of the majority of the world's women.

95 This seems to be what the Liberal feminist push for women in the US military is about.

96 Such a project would be based on assumptions of: difference in values, wants, knowledges and economic goals among peoples within and outside of global capitalism; freedom of choice of modes of production and culture to live in; complementary technologies, infrastructures and resource environments; and compatibility of authoritative decision-making procedures. See Nelson W. Keith, Reframing International Development: Globalism, Postmodernity and Difference (Thousand Oaks: Sage Publications, 1997). 